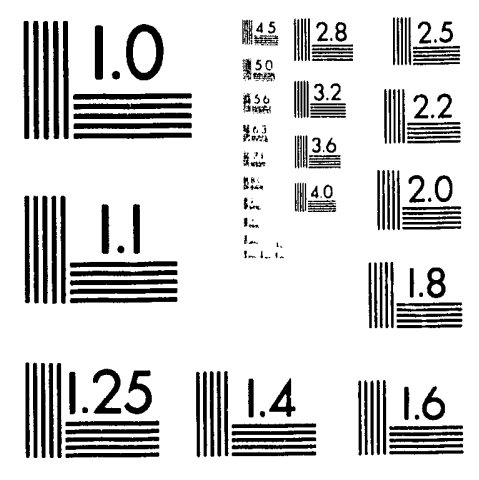



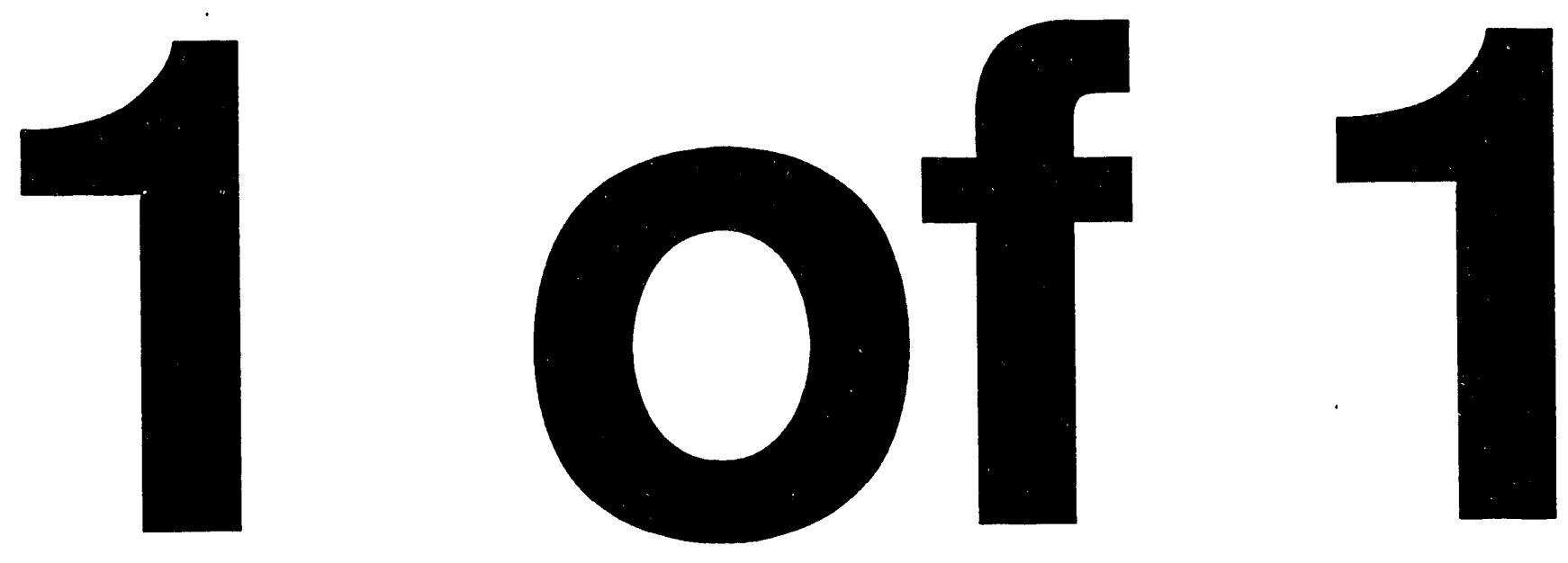
2

$$
\text { Cog } 4.310 .55-2
$$

DOE/METC/C-94/7108

$\mathrm{CO}_{2} /$ Sand Fracturing in Devonian Shale

Authors:

A. B. Yost II (DOE/METC)

R.L. Mazza (Petroleum Consulting Services)

J.B. Gehr (Natural Gas Resources Corporation)

Conference Title:

Society of Petroleum Engineers Annual Technical Conference and Exhibition, Eastern Regional Meeting

Conference Location:

Houston, Texas

Conference Dates:

October 3-6, 1993

Conference Sponsor:

Society of Petroleum Engineers

MASTER

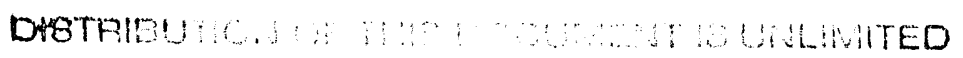




\section{DISCLAIMER}

This report was prepared as an account of work sponsored by an agency of the United States Government. Neither the United States Govemment nor any agency thereof, nor any of their employees, makes any warranty, express or implied, or assumes any legal liability or responsibility for the accuracy, completeness, or usefulness of any information, apparatus, product, or process disclosed, or represents that its use would not infringe privately owned rights. Reference herein to any specific commercial product, process, or service by trade name, trademark, manufacturer, or otherwise does not necessarily constitute or imply its endorsement, recommendation, or favoring by the United States Government or any agency thereof. The views and opinions of authors expressed herein do not necessarily state or reflect those of the United States Government or any' agency thereof.

This report has been reproduced directly from the best available copy.

Available to DOE and DOE contractors from the Office of Scientific and Technical Information, P.O. Box 62, Oak Ridge, TN 37831; prices available at (615) $576-8401$.

Available to the public from the National Technical Information Service, U.S. Department of Commerce, 5285 Port Royal Rd., Springfield, VA 22161; phone orders accepted at (703) 487-4650. 


\title{
SPE/DOE 26925
}

\section{$\mathrm{CO}_{2} /$ Sand Fracturing in Devonian Shales}

\author{
A. B. Yost II, U.S. DOE/METC; R. L. Mazza, Petroleum Consulting Services; \\ J. B. Gehr, Natural Gas Resources Corporation
}

SPE Members

\section{ABSTRACT}

A total of five carbon dioxide $\left(\mathrm{CO}_{2}\right)$ /sand well stimulations were successfully executed with two Devonian shale operators in Perry and Pike Counties, Kentucky. This new stimulation method offers a minimum formation damage proppant stimulation approach for natural gas producers in the United States.

Some operators have been concerned about the frac fluid formation damage associated with the water and chemicals used in conventional foam stimulations, whereas other operators have been concerned about the lack of proppant in straight nitrogen fracs used by service companies today. Two carefully screened geological areas of established Devonian shale production were selected based on active ongoing drilling and completion operations. One selected control area contained an existing set of wells with established production histories.

More specifically, one operator furnished three offset wells which were stimulated with the carbon

References and illustrations at end of paper dioxide/sand frac method. The quantity of proppant and fluids pumped during each well stimulation ranged from 23,000 to 43,000 pounds of proppant and from 120 to 160 tons of liquid carbon dioxide. Another operator furnished two offset wells which were each stimulated with approximately 47,000 pounds of proppant and 120 tons of carbon dioxide.

The logistics and field layout of a typical carbon dioxide/sand frac treatment has been described and highlighted. The importance and unique aspects of the closed system blender that is required for job execution is discussed. Five stimulation treatments have been reviewed, and stimulation and preliminary production data compared to offset wells stimulated with nitrogen, and explosives. Initial production results indicate more than a 50 percent increase in production rate compared to nitrogen fraced wells in the Pike County area. In addition, production is also 4.8 times better than conventional shot wells in the same area. These results are encouraging enough to formally combine existing pumping equipment, a closed system blender, and liquid carbon dioxide 
supplies to develop a new fracturing service in the eastern U.S. A total of 22 additional jobs are planned in the eastern U.S. in low permeability gas formations over the next year.

\section{BACKGROUND/HISTORY}

From a historical perspective, discussion in the public literature concerning the appjication of sand fracturing with carbon dioxide first appeared in $1982^{1}$. It was reported that over 40 liquid $\mathrm{CO}_{2} /$ sand treatments had been performed by American Frac Master in the U.S. by 1982. Early results were encouraging, but frac equipment was moved out of the U.S. shortly thereafter eliminating the opportunity for operators to continue to test the fracturing process in the U.S. Of those 40 treatments, 60 percent were successtul in gas wells, 25 percent were successful in oil wells, and 15 percent were considered noncommercial. Concurrently, during the eariy $1980^{\prime} \mathrm{s}$, more than 40 frac treatments were performed in Canada using gelled liquid $\mathrm{CO}_{2} /$ sand fracs . Early test results indicated a 50 percent increase in production response ${ }^{2}$. Laboratory research proceeded in 1983 toward evaluation of different proppant mesh sizes using a proprietary gelling agent that added viscosity to the liquid carbon dioxide ${ }^{3}$. Subsequently, the continued use of viscous chemicals was suspended in future jobs executed in Canada. Research continued on understanding the mechanics of the $\mathrm{CO}_{2}$ fracturing process and development of a suitable way to improve the rheology of liquid $\mathrm{CO}_{2}{ }^{4}$. Hydrocarbon based gelling agents were tested that would yield over a 2 centipoise viscosity.

During 1985, numerical simulation models were developed for proppant transport that included flow turbulency and its effect on proppant settlement and pressures in the fracture ${ }^{5}$. These numerical simulation models for $\mathrm{CO}_{2} /$ sand fracturing are quite different from conventional stimulation models.

During 1987, additional efforts were focused on methods to create viscosity in the presence of liquid $\mathrm{CO}$, which resulted in the testing of a blend of a high molecular weight fatty alcohol, a sorbitan fatty acid ester and diesel oil representing 2 percent by volume. This component was then combined with liquid $\mathrm{CO}_{2}$ to create a viscous emulsion ${ }^{6}$. A selective number of stimulations were performed in Canada using this emulsion system with mixed results. Shortly thereafter, the use of viscous agents was abandoned in favor of injecting proppant into 100 percent liquid $\mathrm{CO}_{2}$. The obvious benefit was the elimination of residue and formation compatibility associated with the hydrocarbonbased viscous agents. By late 1987, it was reported that more than 450 100-percent liquid $\mathrm{CO}_{2}$ /sand fracs had been performed primarily in Canada $^{7}$. Over 95 percent of the wells were gas wells at depths less than 8200 feet with the largest sand volumes used at approximately 44 tons. Typical sand volume 7 pumped ranged from approximately 10 to 22 tons.

\section{INTRODUCTION}

The U.S. Department of Energy's (DOE) Morgantown Energy Technology Center is chartered to implement the Department's resource and extraction natural gas activities related to gas supply development. As part of the drilling, completion, and stimulation product development activities within DOE's resource and extraction program, development of the appropriate stimulation 
technology for improving the recovery efficiency from conventional and nonconventional gas formations is of major concern. Review of the literature indicated that the technology was available to the U.S. operators for a short period of time in the early $1980^{\prime} \mathrm{s}$ but has since remained outside the U.S. and not available as a commercial service inside the U.S. In an effort to re-introduce this technology to U.S. operators and test the effectiveness of this stimulation technique in various geologic settings, a contract was developed with Petroleum Consulting services to stimulate and test up to 27 wells using the carbon dioxide/sand fracturing methods in the Appalachian Basin.

To date, a total of five single stage stimulations have been completed with 22 additional stimulations planned in the Appalachian Basin over the next year. As part of reintroducing the process to those unfamiliar with the stimulation method, considerable discussion will follow about the history of technology development primarily outside the U.S., discussion of field implementation of job execution, and preliminary results from the early stimulation tests.

The concept of transporting sand in a closed pressure vessel has been under development outside the U.S. since 1981. Although the concept of hydraulic fracturing underground gas formations is not new, the equipment requirements have changed drastically over the years. The $\mathrm{CO}_{2}$ /sand fracturing process ( $\mathrm{Fig}$. 1) differs substantially from conventional treatments in that job execution requires a pressurized blender that can combine liquid $\mathrm{CO}_{2}$ with proppants under pressure. The surface layout of the $\mathrm{CO}_{2} / \mathrm{sand}$ fracturing process (Fig. 2)

identifies the logistical position of the $\mathrm{CO}_{2}$ storage, nitrogen pumper, blender, and pump truck during fracturing operations.

\section{SELECTION CRITERIA}

A candidate well selection methodology was developed to improve the confidence in comparing technology results in various geologic settings. As a minimum requirement, emphasis was placed on providing an established background of production data from control wells to which the production responses from the candidate wells would be compared and an assessment made.

The candidate well selection criteria includes--

1. That the wells are located in accepted areas of legitimate, cost-effective, gas production.

2. That sufficient nearby background production information is available to enable the results of the procedure to be evaluated.

3. That any sand be removed from the wellbore immediately following the stimulation.

4. That the wells be turned in line no later than 30 days after treatment, and that the merits of using this technology be measured from production responses into the pipeline rather than interrupting operator plans for production by conducting an elaborate well testing effort and forecasting indirect indicators of response. 


\section{PROCEDURE - EIELD EQUIPMENT}

Sand proppant is combined with liquid carbon dioxide $\left(\mathrm{CO}_{2}\right)$ in a pressurized blender (Fig. 3) to make a sand/liquid $\mathrm{CO}_{2}$ slurry. The blender is operated at a pressure of approximately 300 psi, and, as presently configured, can store up to 47,000 pounds of sand. It can develop $\mathrm{CO}_{2} /$ sand slurries with densities of up to 5 pounds per gallon at outputs of 55 barrels per minute.

The slurry is discharged directly into the suction side of conventional pump trucks which increase the sand-laden $\mathrm{CO}_{2}$ slurry to wellhead treating pressures and inject it into the wells.

The liquid $\mathrm{CO}_{2}$ is stored in two 60ton portable storage trailers which discharge directly into the blender. They are filled via 20-ton transport trailers prior to these treatments.

During the treatment, the $\mathrm{CO}_{2}$ is displaced from the $\mathrm{CO}_{2}$ storage vessels and into the blender with gaseous nitrogen, which allows a constant pressure to be maintained.

The sand concentration is monitored with a radioactive densimeter throughout the treatment and is adjusted to create the desired sand schedule. All five treatments were executed with the densimeter and resulted in the designed sand schedule being pumped.

Following the treatment, the well is flowed back on a choke. Care is exercised to allow the formation stresses to close on the sand pack and for the $\mathrm{CO}_{2}$ to change to a gaseous phase. Flowbacks required 2 to 3 days.

\section{JOB EXECUTION}

The first series of single stage treatments involved five wells located in Perry (Fig. 4) and Pike (Fig. 5) Counties, Kentucky. They were all completed in the Devonian shale over perforated intervals ranging from 238 to 366 feet, and were selected on the basis of the treatment diversity and quality of the offset production information. They were all treated in January 1993.

The mountainous terrain of eastern Kentucky was the location of the first five treatments, and with one exception, all were treated with equipment on the wellsite. The one well was treated from the base of a hill through 4-1/2-inch casing which had been pressure tested prior to job execution.

The wells were all treated with liquid $\mathrm{CO}_{2}$ and sand. They were all found to have some sand in them, which was removed by various methods: Coiled tubing, with field gas and tubing, and two were sand pumped with exceptional care exercised to minimize water volumes. The sand removal had only a minor effect on the gas production rate, which may be a result of the liquid-free sand pack which remains following the $\mathrm{CO}_{2}$ vaporization.

A summary of candidate well stimulation information is shown in Table 1. The first well (permit no. 83961) was stimulated with 22,700 pounds of $20 / 40$ sand and 120 tons of $\mathrm{CO}_{2}$. A conservative volume of sand was injected to evaluate the ease of introducing sand into the liquid $\mathrm{CO}_{2}$ stream for subsequent injection downhole. The first treatment went very smoothly; therefore, subsequent jobs were executed with the blender loaded to its maximum capacity of 47,000 pounds. The second well 
(permit no. 83962) was stimulated. with 40,200 pounds of $20 / 40$ sand and 160 tons of $\mathrm{CO}_{2}$ resulting in an effective increase from 1.9 to 2.6 pounds per gallon sand concentration. The remaining subsequent jobs were all executed with 120 tons of $\mathrm{CO}_{2}$ and increasing sand volumes up to 46,000 pounds of $20 / 40$ sand at an average concentration of 3.1 pound per gallon sand.

\section{PRELIMINARY RESULTS}

The preliminary results are encouraging, and although only a few months of production is available, the rate of gas production from the $\mathrm{CO}_{2}$ treated candidate wells is greater than that from the control well.s (Tables 2 and 3 ). The average monthly production for the $\mathrm{CO}_{2} /$ sand fraced wells in Perry County is shown in Table 2 . The $\mathrm{CO}_{2} /$ sand fracs appear to be 56 percent better than the nitrogen fracs in Pike County as shown in Table 3 . In addition, the $\mathrm{CO}_{2} /$ sand fracs are 4.8 times better than conventional shot wells in the Pike County study area. It should be recognized that these results are from a very limited data set and overall conclusions may change as more control wells are added to the analysis. From a stimulation process achievement viewpoint, the maximum amount of sand pumped is 46,000 pounds at an average concentration of 3.1 pound per galion. It should be pointed out that additional foam and nitrogen stimulations have recently been performed by the operator in the Pike County area, and subsequent discussions in the future will include additional control wells to the baseline data sets.

\section{CONCLUSIONS}

1. Preliminary monthly production rates of the wells stimulated with $\mathrm{CO}_{2}$ / sand are 56 percent better than nitrogen fraced wells in the Pike County study area.

2. Wells stimulated with $\mathrm{CO}_{2} / \mathrm{s}$ and are 4.8 times more productive than shot wells in the early months of production for the Pike County study area.

3. The long term production from using $\mathrm{CO}_{2} /$ sand fracturing compared to nitrogen and foam conventional treatments needs additional investigation in other areas to verify the broad application of the technology in Devonian shale.

\section{ACKNOWLEDGEMENTS}

The authors wish to thank J. W. Kinzer of Kinzer Drilling and $K$. $I$. Hall of CD\&G Development Company for providing wells of opportunity to test the effectiveness of this stimulation technique. In addition, the authors wish to thank $W$. A. Schuller of EG\&G Analytical Services for his support in selected graphics development.

\section{REEERENCES}

1. Iillies, A. T. and King, S. R.: "Sand Fracturing With Liquid Carbon Dioxide," Paper SPE 11341 Presented at the 1982 Production Technology Symposium, Hobbs, NM, November $8-9$.

2. King, S. R.: "Liquid $\mathrm{CO}_{2}$ for the Stimulation of Low-Permeability Reservoirs," Paper SPE 11616 presented at the 1983 SPE/DOE Symposium on Low Permeability, Denver, Co, March 14-16. 
3. Lillies, A. T.: "Sand

Fracturing with Liquid Carbon

Dioxide," Paper No. 82-33-23

presented at the 33 rd Annual

Technical Meeting of the

Petroleum Society of CIM held

jointly with the 6th symposium

on Engineering Applications of

Mechanics, June 6-9, 1982.

4. Greenhorn, R. C. and Li, E.:

"Investigation of High Phase

Volume Liquid $\mathrm{CO}_{2}$ Fracturing

Fluids," Paper No. 85-36-34

presented at the 36 th Annual

Technical Meeting of the

Petroleum Society of CIM held

jointly with the Canadian

Society of Petroleum Geologists in Edmonton, Alberta, June 2-5, 1985.

5. Settari, A., Bachman, R. C., and Morrison, D. C.:

"Numerical Simulation of

Hydraulic Fracturing Treatments with Low-Viscosity Fluids,"

JCPT (June 1985).

6. Lancaster, G. W., Barrientos,

C., and Greenhorn, R. C.:

"High Phase Volume Iiquid $\mathrm{CO}_{2}$

Fracturing Fluids," Paper

presented at the 38 th Annual

Technical Meeting of the

Petroleum Society of CIM held

in Calgary, June 7-10, 1987.

7. Sinal, M. L. and Lancaster, G.:

"Liquid $\mathrm{CO}_{2}$ Fracturing:

Advantages and Limitations,"

JCPT (Sept to Oct, 1987). 


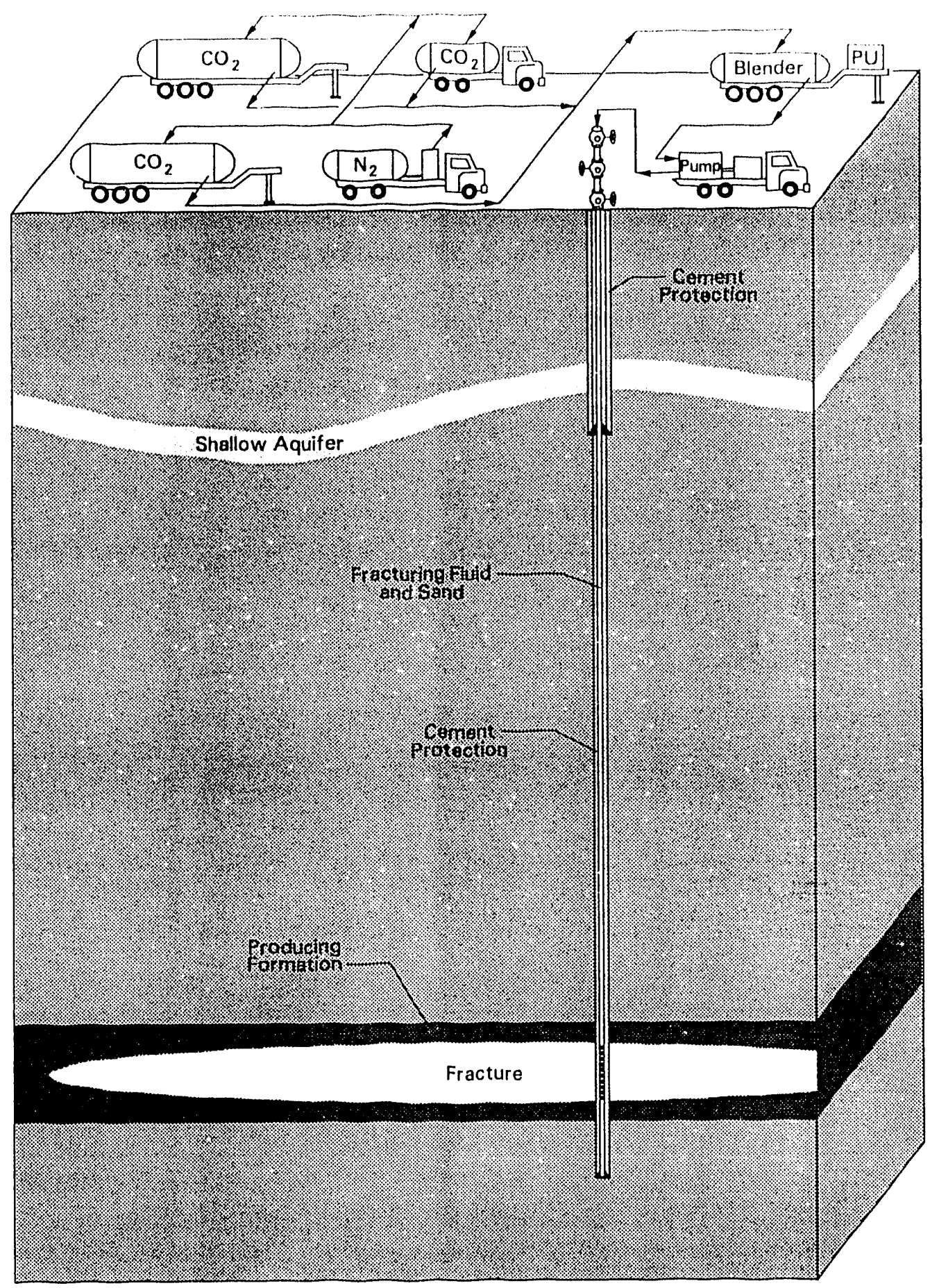

Figure $1-\mathrm{CO}_{2} /$ Sand Fracture Process 


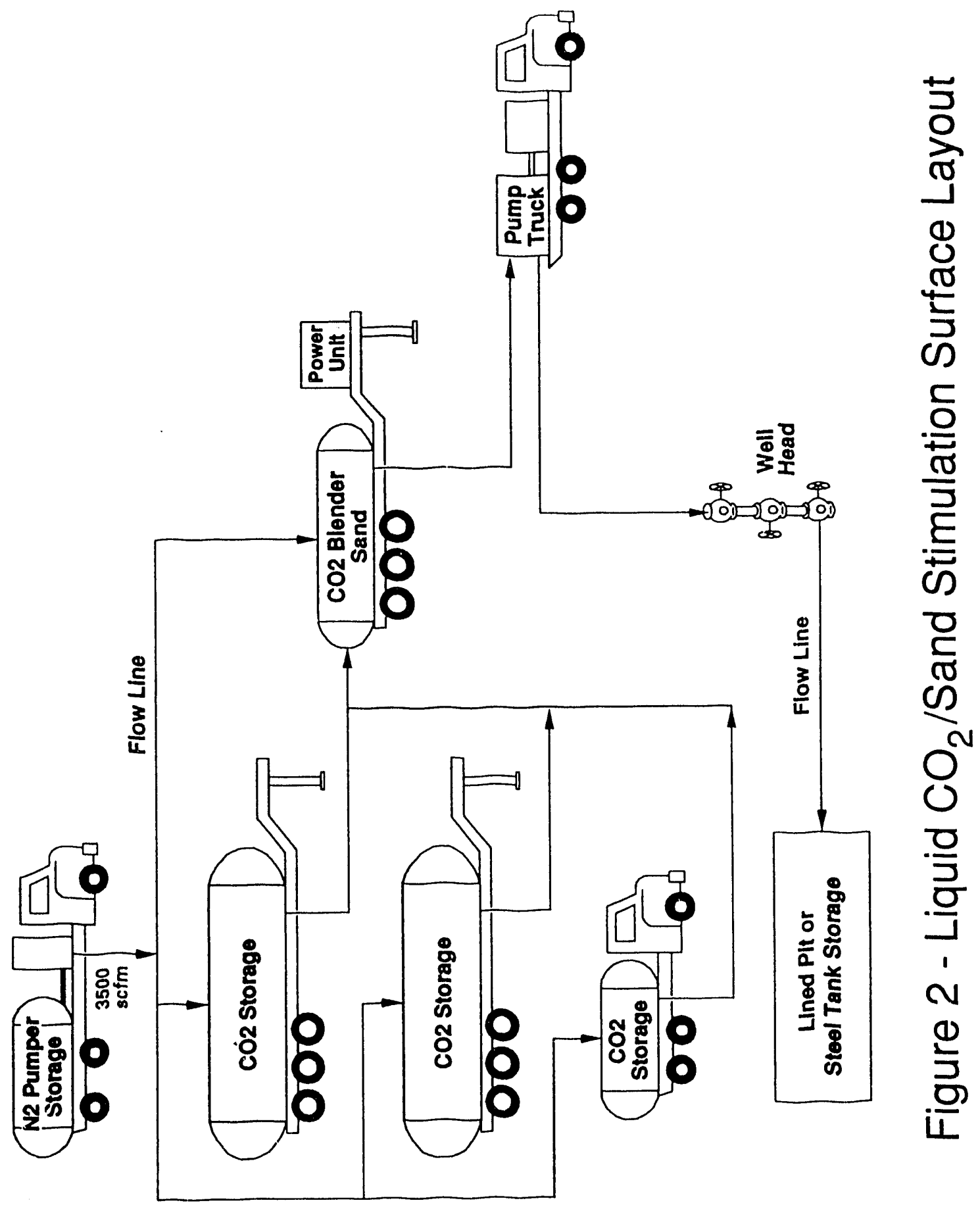




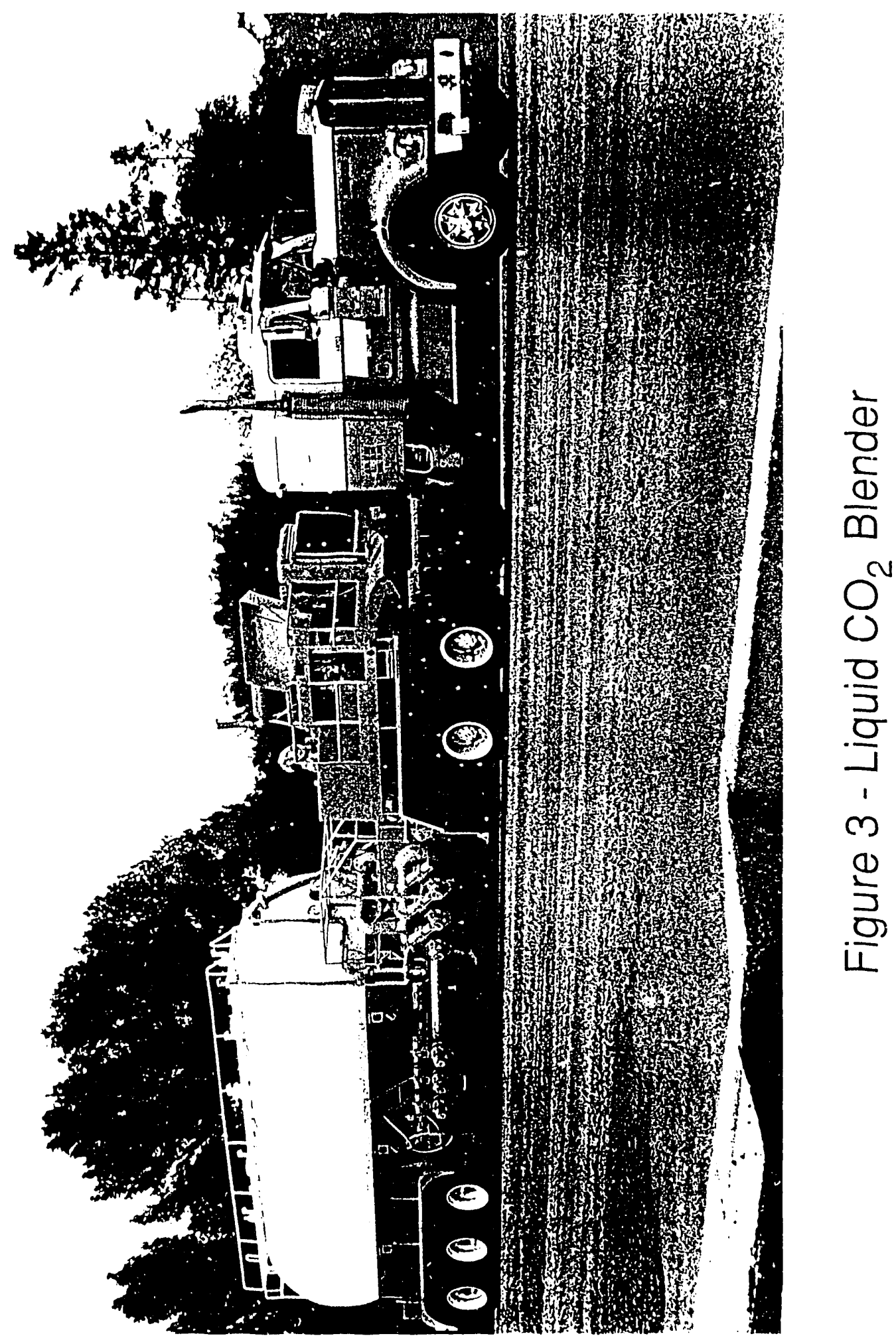




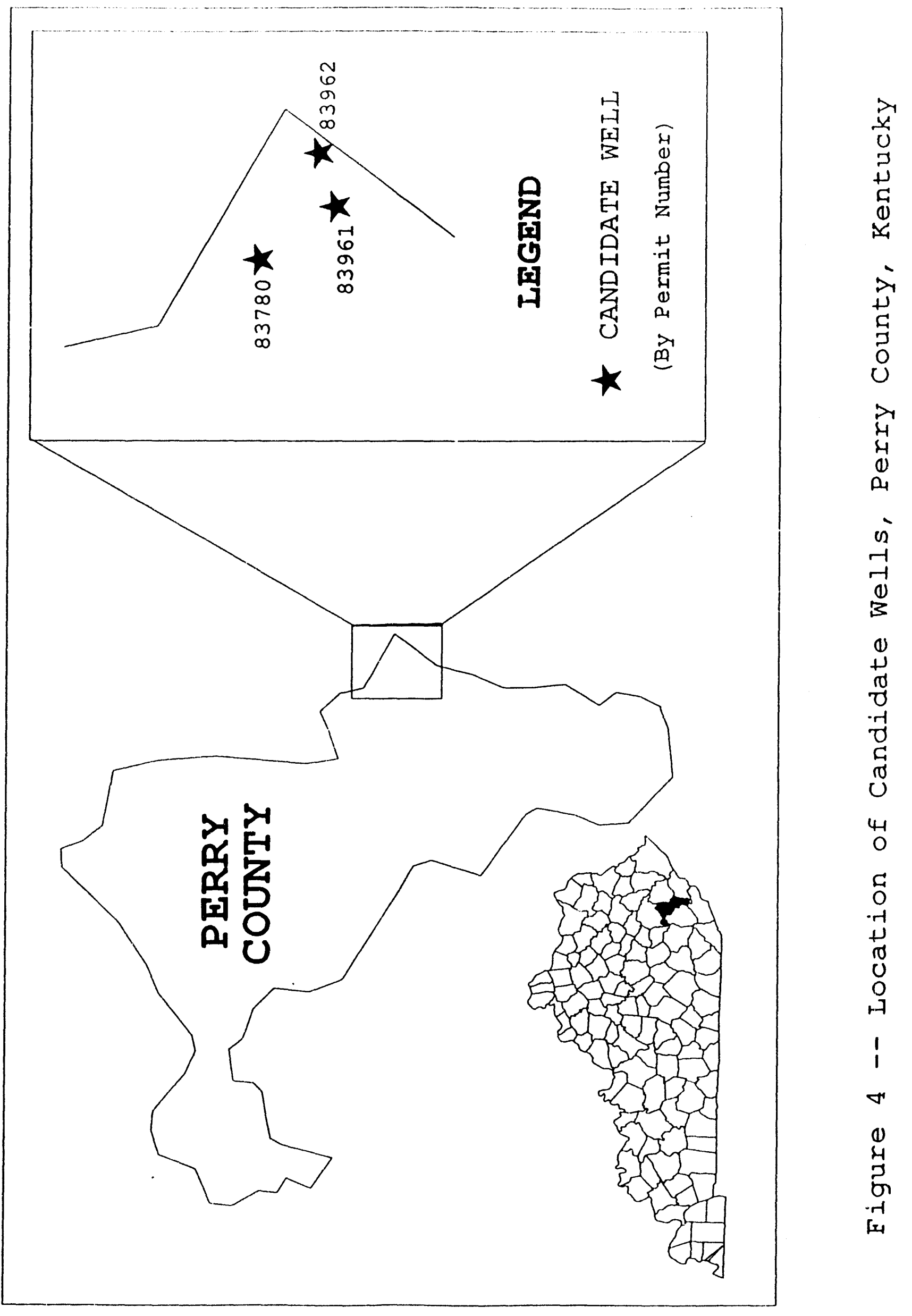




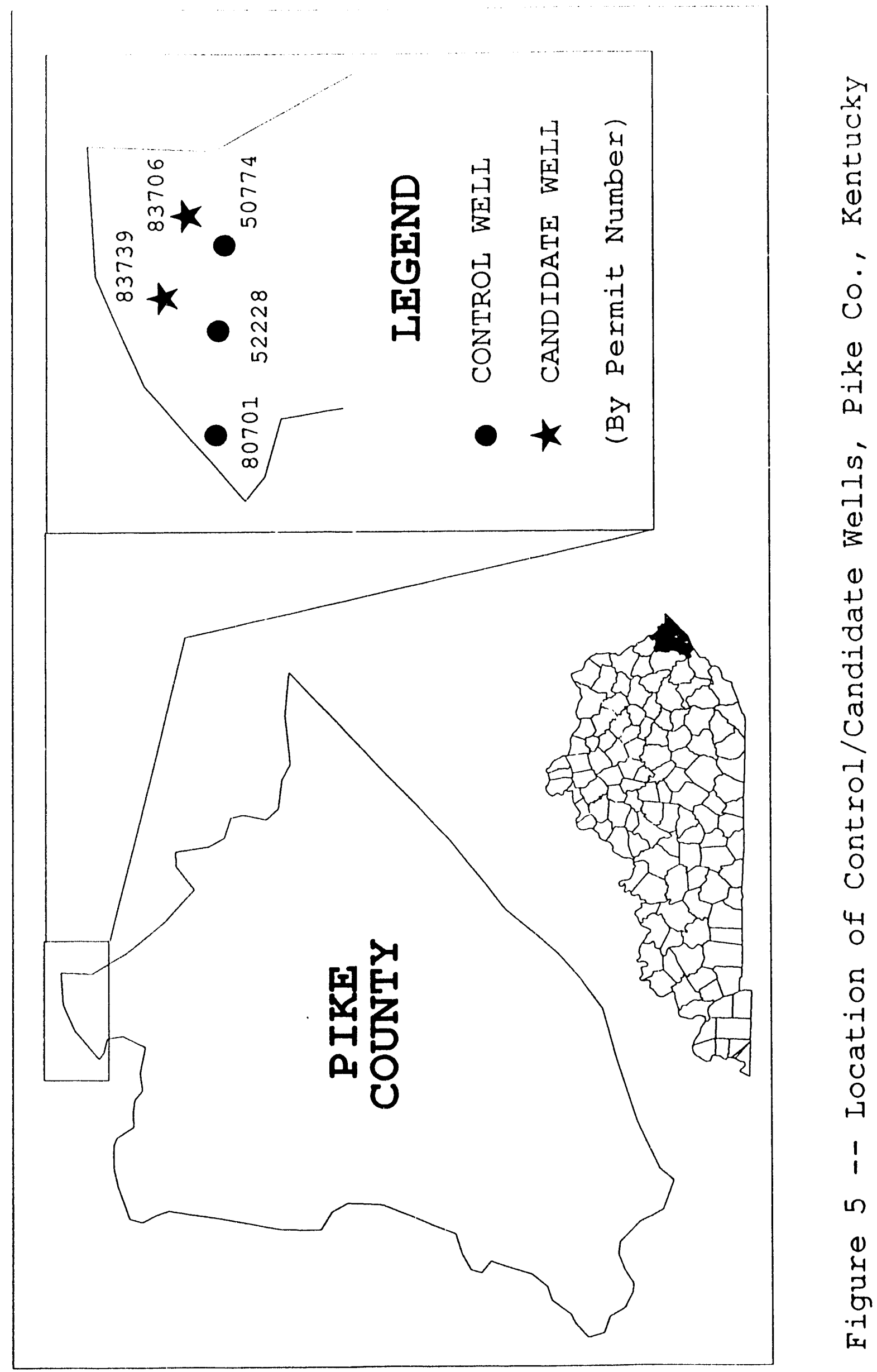


Table 1 - CANDIDATE WELL STIMULATION SUMMARY

\begin{tabular}{|c|c|c|c|c|c|}
\hline $\begin{array}{l}\text { PERMIT \#: } \\
\text { CO/ST: } \\
\text { COMPLETED: }\end{array}$ & $\begin{array}{l}83961 \\
\text { Perry/KY } \\
01 / 08 / 93\end{array}$ & $\begin{array}{l}83962 \\
\text { Pexxy/KX } \\
01 / 10 / 93\end{array}$ & $\begin{array}{l}83780 \\
\text { Perry/KY } \\
01 / 11 / 93\end{array}$ & $\begin{array}{l}83706 \\
\text { Pike/KX } \\
01 / 14 / 93\end{array}$ & $\begin{array}{l}83739 \\
\text { Pike/KY } \\
01 / 17 / 93\end{array}$ \\
\hline $\begin{array}{l}\text { PERFS : } \\
\text { TOP : } \\
\text { BOT: }\end{array}$ & $\begin{array}{r}19 \\
2976 \\
3342\end{array}$ & $\begin{array}{r}17 \\
3412 \\
3748\end{array}$ & $\begin{array}{r}18 \\
33.32 \\
3666\end{array}$ & $\begin{array}{r}22 \\
2984 \\
3248\end{array}$ & $\begin{array}{r}18 \\
3162 \\
3400\end{array}$ \\
\hline INTERVAL: & 366 & 336 & 334 & 264 & 238 \\
\hline $\begin{array}{ll}A C I D & \text { (GAL) : } \\
\mathrm{CO}_{2} & \text { (BBLS) : } \\
& \text { (TONS): }\end{array}$ & $\begin{array}{r}0 \\
115 \\
(120)\end{array}$ & $\begin{array}{r}0 \\
131 \\
(160)\end{array}$ & $\begin{array}{r}500 \\
96 \\
(120)\end{array}$ & $\begin{array}{r}300 \\
95 \\
(120)\end{array}$ & $\begin{array}{r}300 \\
95 \\
(120)\end{array}$ \\
\hline $\begin{array}{l}\text { PAD (BBLS): } \\
\text { SL (BBLS): } \\
\text { FLUSH (BBLS) : }\end{array}$ & $\begin{array}{r}240 \\
338 \\
70\end{array}$ & $\begin{array}{r}255 \\
463 \\
38\end{array}$ & $\begin{array}{r}106 \\
435 \\
27\end{array}$ & $\begin{array}{r}121 \\
419 \\
22\end{array}$ & $\begin{array}{r}135 \\
408 \\
21\end{array}$ \\
\hline $\operatorname{PMP}$ (BBLS): & 648 & 756 & 568 & 562 & 564 \\
\hline $\begin{array}{l}\text { SAND (SXS): } \\
\text { IN WELL: }\end{array}$ & $\begin{array}{r}2 i j \\
18\end{array}$ & $\begin{array}{r}425 \\
23\end{array}$ & $\begin{array}{r}460 \\
31\end{array}$ & $\begin{array}{r}440 \\
10\end{array}$ & $\begin{array}{r}470 \\
10\end{array}$ \\
\hline NET $(S X S):$ & 227 & 402 & 429 & 430 & 460 \\
\hline MESH : & $20 / 40$ & $20 / 40$ & $20 / 40$ & $20 / 40$ & $20 / 40$ \\
\hline $\begin{array}{l}\text { N2 (MCF) : } \\
\text { RATE (BPM) }\end{array}$ & 67 & 100 & 84 & 88 & 72 \\
\hline $\begin{array}{c}\text { AVG: }^{\text {AVGSS (PSI) }} \\
\text { PRESS }\end{array}$ & 42.3 & 44.3 & 35.2 & 43.4 & 33.2 \\
\hline $\begin{array}{r}\text { AVG: } \\
\text { SND CONC (RPG) }\end{array}$ & 2064 & 2804 & 1171 & 2195 & 3187 \\
\hline RSEPOWER & 1.9 & 2.6 & 2.8 & 2.9 & 3.1 \\
\hline AVG: & 2140 & 3045 & 1010 & 2335 & 2593 \\
\hline
\end{tabular}



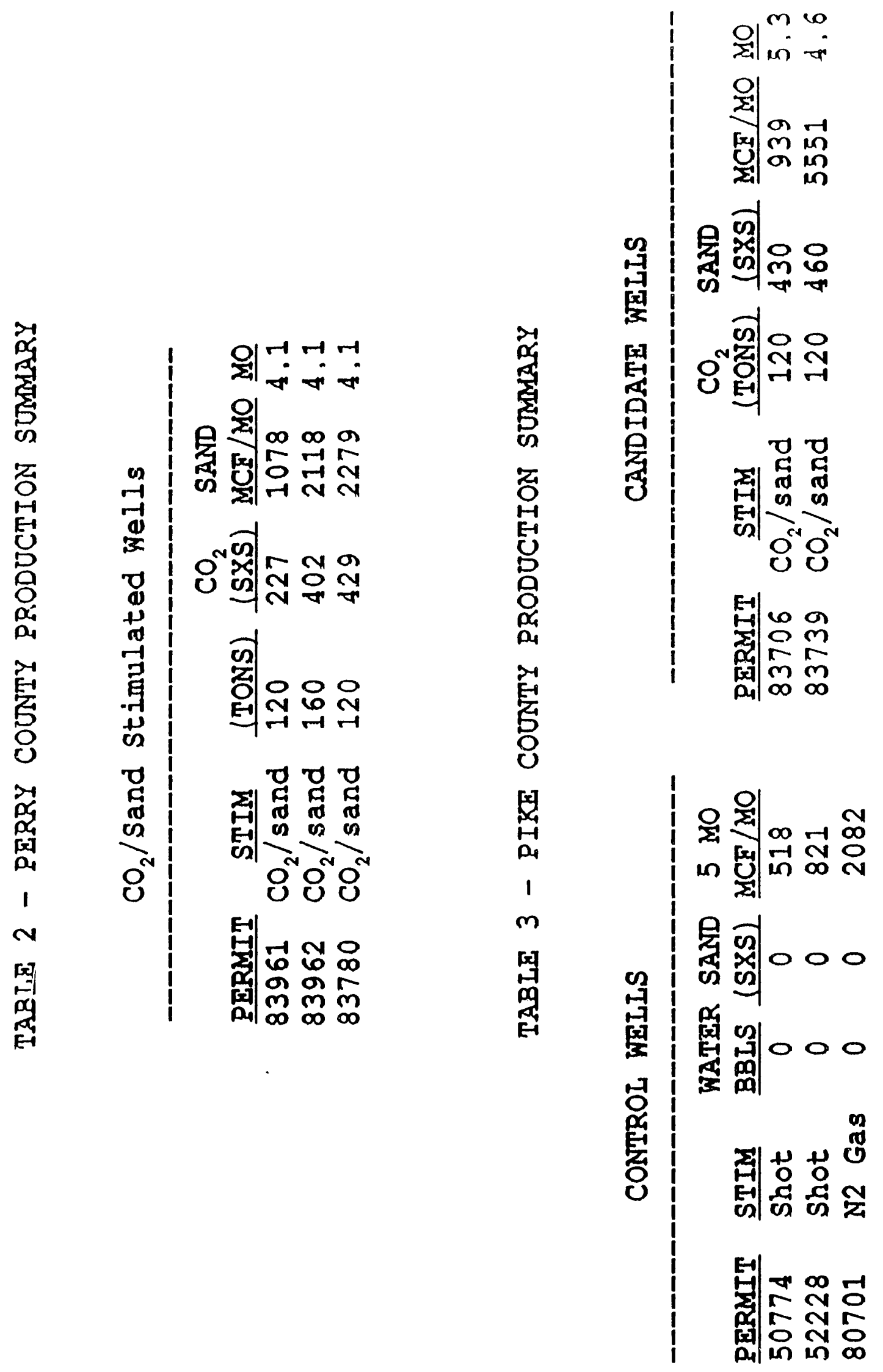

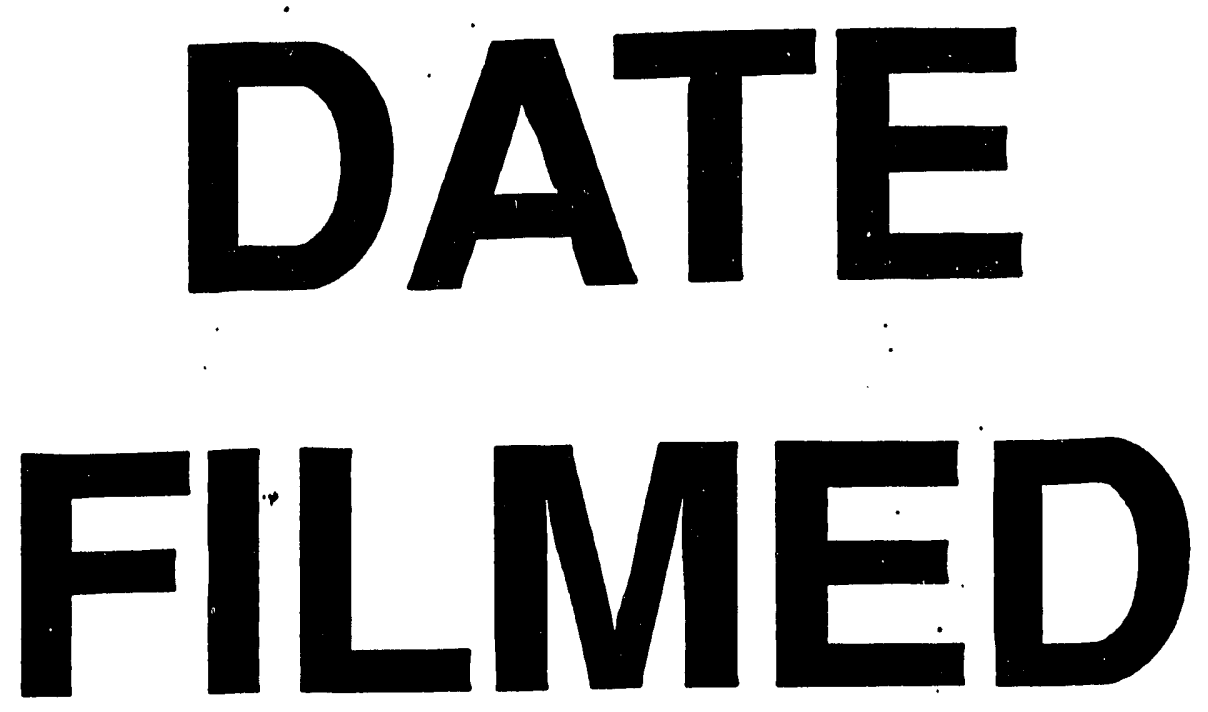

$12 / 27 / 93$
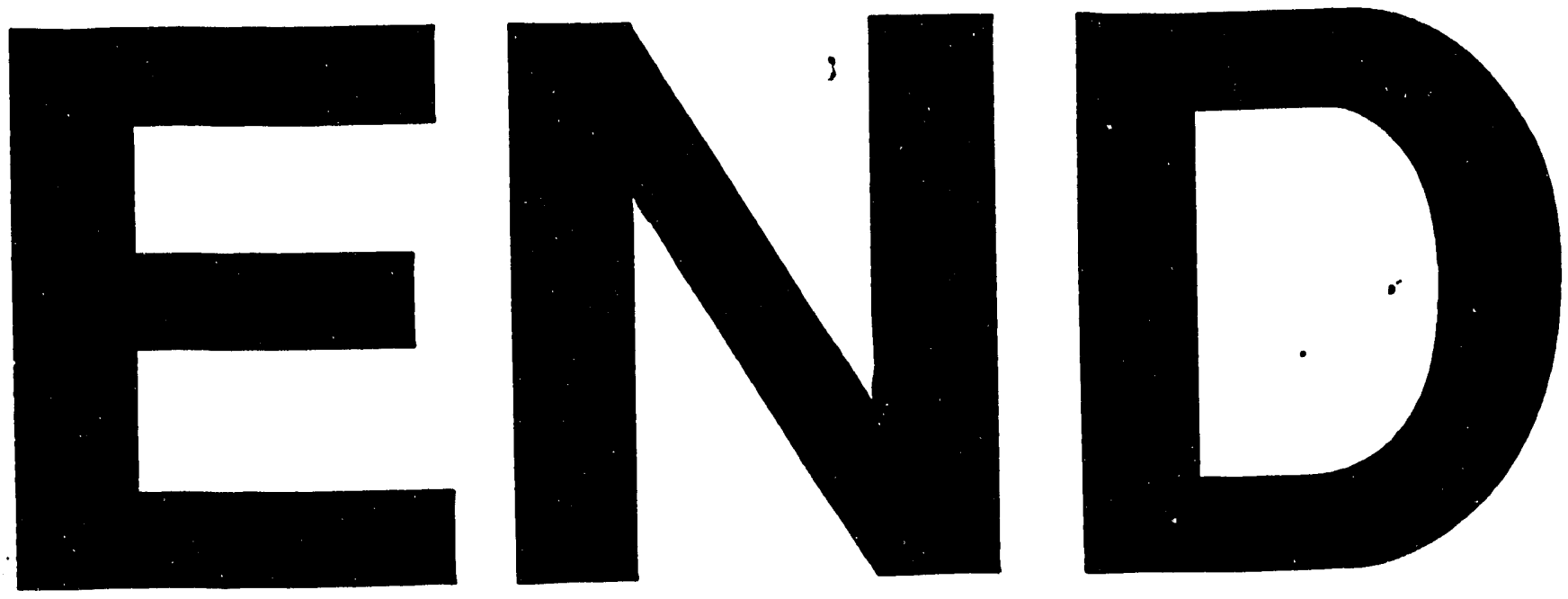
